\title{
A Hard Act to Follow
}

Correspondence for Reference and User Services Quarterly should be addressed to Editor Diane Zabel, Schreyer Business Library, The Pennsylvania State University, 309 Paterno Library, University Park, PA 16802; e-mail:dxz2@psu.edu.
I have been involved with our division's journal for more than seventeen years, first as a reviewer of reference books, and for the past seven years as the editor of the Alert Collector column. I am humbled to have this opportunity to assume a larger role with the journal. I know that I will need to work hard to continue the legacy of the many esteemed editors that came before me. In particular, I am profoundly aware that my immediate predecessors will be a hard act to follow. While Bill Katz edited the journal for the most consecutive number of years (ten), Connie Van Fleet and Danny Wallace have the distinction of editing the journal for the greatest number of years (twelve in total). What is even more remarkable is that they made it look so effortless all these years (and, of course, it is not, as editing a journal is hard work).

Thanks to Van Fleet and Wallace's diligence, RUSQ has retained its status as a premier publication for academic and public librarians engaged in reference and user services. Their own contributions to the journal have significantly impacted our profession. Their cleverly titled spring 2002 editorial, "O Librarian, Where Art Thou?" has been widely cited and was integral to the 2002 RUSA President's Program on staffing and recruitment. In fact, it has become a seminal work on recruitment to the profession. Because they did such an excellent job of promoting RUSQ as a publication venue, the number of manuscript submissions has increased significantly during their most recent tenure as editors. Consequently, I will be working through an acceptance backlog. On a personal note, I want to thank Connie and Danny for all their help in orienting me to the editorial process to ensure a smooth transition. Additionally, JoAnn Palmeri and Rachel Mosman, their editorial assistants, graciously assisted me with the preparation of this issue.

I strongly believe that one of the missions of RUSA is to respond to the continuing education needs of the Division's membership. Many members are unable to attend Midwinter Meeting and Annual Conference. Consequently, RUSQ plays an important role in serving the continuing-education needs of the entire RUSA membership. I view RUSQ as a forum for librarians to learn from one another. I strongly believe in the importance of research as a tool for strengthening professional practice. The journal must provide a balance of practical and empirically based articles on problems and issues that widely impact reference and public-services librarians. Librarians seek out thoughtful articles on new public-service configurations, alternate modes of reference service, innovative instruction, the impact of e-resources on reference and collection development, strategies for improving and marketing library 
services, institutional cooperation, and other timely topics. RUSQ is a vehicle to share information about these issues.

The next few years will be critical ones for RUSQ. Findings from the 2005 readership survey conducted by Readex Research provide data on how well RUSQ currently meets the needs and interests of RUSA members. It also provides a measure of readers' interest in a digital version of the journal. This four-page readership survey was mailed to a random sampling of one thousand RUSQ readers and had a 54 percent response rate. As a follow-up to the survey, professionally facilitated focus-group interviews were conducted at the 2006 Midwinter Meeting to provide additional insight on the expectations of both public and academic librarians regarding the journal.

Data from the readership survey provide a profile of readers and their preferences for future content. RUSQ readers are engaged with the journal. A typical recipient has read all four of the last four issues, spending forty-nine minutes reading or browsing each issue. Seventy-nine percent of recipients indicated that they do something as a result of reading an article or column. They visit Web sites, order a product, file articles for further reference, discuss articles with others, or pass along items to others. In fact, one out of three readers passes along issues to others, which significantly increases the journal's readership.

The journal is well regarded; almost 91 percent of recipients reported that they find the information credible. RUSQ also ranked high in categories involving thoroughness, timeliness, ease of reading, and attractiveness. However, readers indicated a very strong preference for more practical articles. The focus-group data confirm this preference for the practical over the theoretical.

While there were indications that readers would respond favorably to an online version (especially one incorporating dynamic links and access to full-text), one of the most surprising findings from the readership survey was that there is a strong preference for print over online. Seventy-one percent of respondents indicated that they prefer a print version compared to electronic ( 9 percent) or both print and electronic (18 percent). However, the focus-group data indicate that readers would welcome an electronic version that includes access to the full-text of current and previous issues, dynamic links, interactive features (including threaded discussions and opportunities to communicate with authors), and functional features (such as e-mail alerts, the ability to e-mail a link to colleagues, and good use of color and graphics). Given this feedback, I have asked Michael Stephens (www.tametheweb .com), a well-known blogger highly regarded for his technological expertise, to serve as a consultant to production staff on the development of an interactive online companion to RUSQ.

According to the readership survey, RUSQ readers are seasoned professionals, with median tenure of employment at seventeen years. Many readers have assumed managerial responsibilities, as 26 percent of respondents indicated "administration/management" as a job function. Consequently, there may be a need for more advanced practical information in the journal. One-third of recipients worked in public libraries while more than half (53 percent) worked in academic libraries. Among the broad topics of high interest to readers are collection development, frontline and virtual reference services, readers' advisory, and reference and user services in public libraries.

The readership survey included an open-ended question asking recipients to list topics they would like to see covered in future issues. Respondents provided great ideas for future content. Among the topics suggested were the following:

- best practices;

- assessment of reference and user services;

- publishing trends and the impact on collection development;

- use of new technologies such as podcasting and blogs to market library services;

- administrative/managerial topics such as staffing, training, and personnel issues;

- development of policies and procedures ranging from cell-phone use to the use of public computers;

- diversity issues ranging from serving diverse populations to the development of a diverse staff;

- federated searching;

- e-learning and its impact on libraries;

- future trends as well as a look back at our profession;

- advice for new librarians;

- career development;

- adult programming;

- library as place;

- impact of technology on all aspects of librarianship; and - copyright and fair use.

I am particularly pleased that copyright and fair use is the theme of this issue's Alert Collector column.

There will be some changes for the journal as a result of the readership survey and focus-group discussions. One of the findings from the focus groups is that readers want RUSQ to include more color and graphics. As a result, I worked with ALA Production Services to create a redesign of the journal's layout. I want to thank Stephanie Kuenn, Christopher Keech, and Christine Velez for their effort to create a design that we hope you will find crisp, clear, and contemporary. In response to feedback from the readership survey, I have added a column that will focus on technology twice a year and on management twice a year. That column will debut in the next issue. I am delighted to announce that Kathleen Kern will serve as editor of the technology column and Judith Nixon will serve as editor of the management column. In terms of other changes, Neal Wyatt has taken my place as editor of the Alert Collector column, and the Community Building column has been discontinued. I am pleased to report that Beth S. Woodard and Lori Arp continue as editors of the Information Literacy and Instruction column and Barry Trott continues as editor of the Readers' Advisory column. Carolyn J. Radcliff 
is continuing as Reference Books editor and Karen Antell will be continuing in her role as the Professional Materials editor.

I am also pleased to announce several new appointments to the RUSQ Editorial Advisory Board: Judith M. Arnold, Gwen Arthur, Corinne Hill, Jessica E. Moyer, Amber E. Prentiss, and Michael Stephens. These individuals bring interesting and diverse perspectives to the board and I appreciate their willingness to take on this important assignment. I am also thankful for the four continuing board members (Robert V. Labaree, Dale McNeill, Douglas Raber, and Kathleen A. Sullivan) who will provide continuity and guidance. I am looking forward to working with all the editors, editorial-advisory board members, and staff at ALA Production Services to incorporate changes and suggestions that you, our readers, have put forward for consideration.

\section{New from Sharpe Reference}

\section{Postwar America}

An Encyclopedia of Social, Political, Cultural, and Economic History

\section{Edited by James Ciment}

From the outbreak of the Cold War to the emergence of the United States as the last remaining superpower, the years following World War II have been filled with momentous events and rapid change. This sweeping A-Z encyclopedia provides detailed coverage of the economic, political, social, and cultural developments in America during these years, and also examines their dramatic influence around the globe. It includes a Topic Finder, Cultural Landmark entries, sidebars and illustrations.

2006 • Four volumes, 8-1/2" x 11"

Topic finder, cultural landmarks, A-Z entries, photos, glossary, bibliography, multiple indexes.

0-7656-8067-X Hardcover $\$ 399.00$ / set

\section{New Edition}

\section{Encyclopedia of Conflicts Since World War II}

Second Edition

\section{Edited by James Ciment}

Thoroughly revised to include 26 conflicts not covered in the previous edition, as well as expanded and updated information on previous coverage, this illustrated reference

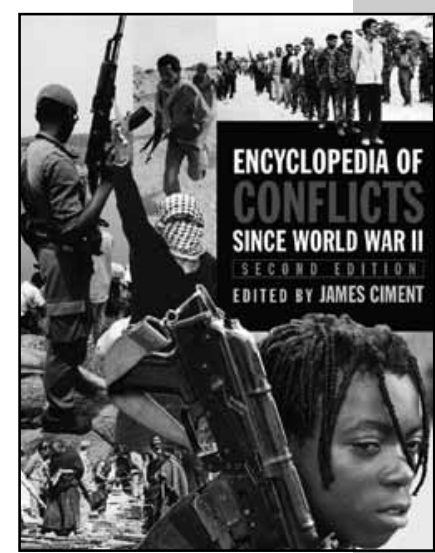
presents descriptions and analyses of more than 170 significant post-World War II conflicts around the globe. Organized by region for ease of access, the set includes more than 180 detailed maps and 150 photos. It offers unmatched coverage of the conflicts that dominate today's headlines and the events that changed the course of late twentieth-century history.

Winter 2006-07 - Four volumes, 8-1/2" x 11"

Photos, maps, glossary, bibliography, index. 0-7656-8005-X Hardcover $\$ 439.00 /$ set Prepublication Price: $\$ 395.00$ until 12/31/2006

Sharpe Reference is an imprint of M.E. Sharpe TO ORDER: Call 800-541-6563 • Fax 914-273-2106

Online at www.mesharpe.com

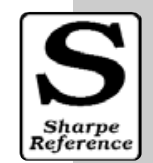

